\title{
DRIVING FROM THE BACKSEAT: AN EXPLORATORY STUDY OF THE DEARTH OF MALAYSIAN WOMEN IN POLITICAL DECISION-MAKING PROCESS
}

\author{
${ }^{1}$ Imam-Tamim, ${ }^{1}$ Muhammad Kamaldeen, ${ }^{2}$ Najibah Mohd Zin, ${ }^{2}$ Norliah \\ Ibrahim \& ${ }^{2}$ Roslina Che Soh \\ ${ }^{1}$ Department of Private and Property Law \\ Faculty of Law, University of Ilorin \\ ${ }^{2} \mathrm{AIKOL}$, Islamic International University Malaysia \\ (lawyertamim@gmail.com)
}

\begin{abstract}
The place of women in decision-making at various strata of living has been a front-burner issue in the current milieu. The population of women in Malaysia is almost as equal the population of men. The Malaysian women have been found to excel in academic and even professional labour market than the men. Thus, they are naturally imbued with the skills and intellectual capabilities to contribute to the Malaysian national development. Notwithstanding the perceived superiority in the intellectual capability of the Malaysian women, the number of women allowed to participate in nation building in the country is abysmally low. Researchers have shown that the women have been facing challenges in assuming political positions where they can adequately and practically contribute to national development. The paper is an exploratory legal research. Therefore, employing an analysis of both primary and secondary documentary data, the paper investigates the factors that contribute to the inhibition of Malaysian women in this regard despite their landmark educational and professional progressions and achievements. The paper argues that Malaysia will profit better in its national development and nation building programmes if more women are allowed to participate in national governance. There is, therefore, the need to introduce fresh approaches and perspectives to the current efforts by the Malaysian government to ensure that it keeps up with its commitment towards the millennium development goals.
\end{abstract}

Keywords: women, decision making, national governance, Malaysia. 
Driving from the Backseat: An Exploratory Study of the Dearth of Malaysian Women in Political Decision-Making Process

\section{Introduction}

Malaysia has a considerable population of women who are almost as equal the population of men. According to the Malaysian population clock, as at $25^{\text {th }}$ day of December, the year 2014, the country's population comprises 50.7 percent males and 49.3 percent females (Country Meters, 2014). The Malaysian government has the since the year 2000 been taking steps towards elevating the status of women (United Nations, 2005). This has culminated in the development of different gender sensitive policies, creation of several gendersoriented state institutions and financial support to gender-based organisations. These efforts have led to rapid increase in the number of girls that attend schools. This is not only bridged the yawning gap between male and female students at primary schools, but it also leads to the number of female students in secondary and tertiary institutions surpassing that of the male. According to a recent statement credited to Dr Mahathir, the females constitute 70 percent of the schools' population (Rahim 2014; Baradan, 2014). The increase in education of female has consequently contributed to finding more females in almost all areas of the labour sector ranging from the professional to the menial jobs. In fact, a United Nations report (2005) showed a significant increase of female in professional jobs and attributed this to the increase in education. The dominance of female in schools and the workplaces is attributed to higher intelligence and commitment of the females than their male counterparts (Ka Chuan, 2006; Pua, 2006; Pua, 2005). Although this proposition has been disproved by various studies (Mazruki et al., 2012; Ngah, Jusoff \& Abdul Rahman, 2009; Khalili, n.d.), the findings in the studies contradicts an official report by the United Nations that females consistently outperforms the males in both the primary and secondary schools' national examinations (United Nations, 2011, 40, 42 \& 48).

However, notwithstanding the abundant availability of educated and qualified Malaysian women, their roles in the political positions and decisionmaking processes in the country have been very significantly low. Recently, the UMNO women leader advocated for adequate role for women in decisionmaking positions (Abdul Jalil, 2013; UMNO Wanita, 2013) and has been advocating for the post of vice president for women in the ruling party (Abdul Jalil, 2013; "What is Shahrizat up to?", 2014; Tan, 2014). The reason is the presence of Malaysian women in political positions where they can contribute meaningfully to decision and policy making processes is abysmally low. The women still find it difficult to attain poll positions in the national political structure. 
This paper explores the current state of Malaysian women in contributing to development and nation building and identifies some of the factors inhibiting their potentialities inadequately contributing to development and nation-building in the country.

\section{Literature Review}

Malaysia has taken various steps since Merdeka to improve human development through reduction of poverty. In the year 2005, it was declared that the country had met all the Millennium Development Goals (Smiling, 2011; United Nations, 2005). One of the goals is the effort of government to ensure that both women and men have equal access to basic social amenities coupled with series of policies geared towards ensuring that more women are integrated into the development processes while still maintaining their traditional roles at the family, community and society levels (Smiling, 2011). This, it is believed, has enabled some women to contribute significantly to national development but the extent to which the women folk could contribute equal quota of development to the national polity as their male counterparts is greatly limited due to certain cultural inclinations and practices that hamper their participation in decision-making and development processes (United Nations, 2005).

Since the year 2000 when Malaysia joined other nations at the Millennium Summit in making commitment to ensure gender equality (United Nations, 2005), the government has taken efforts towards achieving this goal, and encouraging results are believed to have been gotten. For instance, in 2005, Richard Leete reported that the high rate of gender disproportion that characterised the Malaysian educational institutions was drastically reducing (see United Nations, 2005). It was observed that females have geometrically outnumbered the males especially in secondary and tertiary institutions (Kalthom Abdullah, Noraini M. Noor and Saodah Wok, 2008; Rahim 2014; Baradan, 2014; Ka Chuan, 2006; Pua, 2006; Pua, 2005). This fact is supported by other International reports (United Nations, 2011; OECD, 2009; ADB, 2007). Consequently, the numbers of women who are literate, employable and intellectually qualified to hold decision and policy making positions also outnumber their male counterparts. But the number does not reflect when it comes to holding the position of power and their involvement in the decisionmaking process. The United Nations (2005) explained that the obvious reason for the dearth of women at a highly placed executive level in the labour market is because more women pull out of a job either when they marry or most often 
when they start to give birth, and they rarely return to work after they stop birth. The reports contrasted this phenomenon to the situation in some other countries with which Malaysia shares similar aspiration. In those countries, women are neither forced nor encouraged to leave their job because of childbearing, and if they do, they are always reintegrated as soon as they stop childbirth (United Nations, 2005). Official statistics also point to the fact that despite being more qualified, more women are unemployed (see United Nations, 2011). Also, the current most active labour sector, the administrative and managerial subsector still has fewer female employees than male (see Malaysia, Department of Statistics, Labour Force Survey Reports, 2003, 2002, $2000,1998,1990,1980$, and 1975). Although there is a claim that the trend of the females getting employed in the subsector is increasing, the rate of growth is significantly slow (see Kalthom Abdullah, Noraini M. Noor and Saodah Wok, 2008). In a 2001 report, it was found that the women constituted 36 percent of the Malaysian workforce (Women's Aid Organisation, 2001). Although a report by the Department of Statistics (2013) shows that the rate has increased in 2010 and 2011 to 46.8 percent and 47.9 percent respectively, the report further shows that their participation rate has started to decline again. This is opposed to the population of females who are more literate and educated than the men.

One of the factors being blamed for the lagging of women in decisionmaking positions is the philosophical system that lies beneath the dominant culture in the society (United Nations, 2010). The philosophy is, in turn, hinged on religion, which mainly governs the ethical structure of the society (Ali and David, 2013; Abdullah, 2011). Whichever way the debate goes, it has been noted that religion, ethics, culture and tradition are so intertwined that to determine which of them contributes most to gender inequality will be a herculean task (Gross, 1993; Ahmed, 2002; Mananzan, 2004; Rosenlee, 2006). Smiling (2011) and Women's Aid Organisation (2001) however observed that even though the various religions and cultures applicable in Malaysia contain norms that are capable of positively elevating the status of women, there are yet some other norms that distinctly relegate the women's status and prevent them from contributing meaningfully to national development. It was further noted that such norms sustain the stereotyping of gender roles and engender patriarchal societal attitudes towards them. So, the women are culturally expected to be more active only in domestic front, that is, to stay at home as the homemakers and mothers. For those privileged to work, they are expected to give their salaries to their husbands while many who were working before marriage were forced to give up their jobs when they marry to fulfil their 
traditional roles as mothers, wives and home keepers (United Nations 2011; Women's Aid Organisation, 2001). It was also observed that even the establishment of Ministry of Women's Affairs has not been able to rectify the cultural anomaly as its creation only further emphasises the place of women in the home and family life thereby depicting other roles of the women in the society as secondary (Smiling, 2011; Women's Aid Organisation, 2001). However, while this argument may be true in some respect, Haji Faisal's (1984) explanation of the role of Malay women in political sector from the perspective of Islam (which is the dominant religion and forming the foundation for the dominant Malay culture in the country) shows that the religion has strong support for their active participation in decision-making processes. It was thus concluded that Islam does not prohibit women from participating in the nation building. Karim (1992) also shows that Malay traditions especially safeguards the right of women in active politics and government and that they are indeed given roles to national political parties but noted that the concept of male dominance as a 'natural' phenomenon had curtailed their ability to compete equally with men in the national arena of politics. The women find it difficult to advance in the same sphere of public activities as men who manipulate the modern bureaucratic political structures to their advantage (Karim, 1992). This position is buttressed by Datuk Seri Shahrizat Abdul Jelil, the national women leader of the UMNO, who claimed that her call for the creation of a vice president position for women had not gotten a positive response from the male politicians ("What is Sharizat up to?", 2014).

Buttressing Smiling's position, the United Nations (2010, 2011) and Women's Aid Organisation (2001) in separate reports noted that even though Malaysia is fast becoming one of the countries having high human development index (HDI). This efforts to substantially elevate the status of the women and integrate them into decision-making process is being marred by some inhibiting factors prominent among which is traditional gender roles informed by culture. It is observed that Malaysian societies, like in other Asian countries still operate largely based on culture and tradition. These cultures and traditions place much premium on family structure, which is considered as the most important institution in the society. And the operation of the family is run within the milieu and demarcation of gender roles for each sex (Inoguchi and Newman, 1997). The attitude of the traditions and cultures to the role expected to be played by each gender in the larger society is believed to have impinged on effective participation of many women in decisionmaking processes. This is especially politics thereby preventing them from adequately contributing to national development as done by their peers in 
other jurisdictions (United Nations, 2010). The attitude is equally considered as a significant trammel on the effectiveness of the national plans and policies made by the country for the enhancement of the women status. It is nonetheless admitted that the country has established several encouraging socio-economic policies especially by creating innovative and gender-focused laws, institutions and agencies, creating an enabling environment for the formation of women organisations and allocating not less than RM 20 million annually for them (United Nations, 2005; United Nations, 2010).

Although there are statistical data showing that women comprise almost half of the entire Malaysia population with 49.3 percent (Country Meter, 2014), yet their presence in decision-making structures of the country is insignificant. For instance, it has been shown that one of the areas of the national development where the impact of the women ought to have been felt particularly in the area of decision-making and developmental role play is the media industry because of the large percentage of the women in the industry but that has not been the case (Azman Azwan Azmawati, 2008; Mohd. Hamdan Adnan, 1987; Azman Azwan Azmawati and Juliana Abdul Wahab, 2005). Rather, the women are always generally depicted as stooges of the men. That is some sort of second class citizens in their society. It is thus found that the media products, like dramas, news and other locally produced women programmes, reflect the traditional stereotypical depiction of women's roles as secondary and subordinate character in both domestic and national development (Wang Lay Kim (1994); Wang Lay Kim and Mustafa Kamal Anuar (1996) and Wang Lay Kim (2000); Mustafa Kamal Anuar and Wang Lay Kim (1991, 1994); Azman Azwan Azmawati and Juliana Abdul Wahab (2005)).

According to Guimond et al. (2006), strong gender differences is common among cultures where there are strong social comparisons concerning the kind of attributes and roles that must be assumed by each gender group. Although findings by Williams \& Best (1986) suggests that stereotyping of gender roles appears to be a trans-cultural phenomenon, yet Guimon et al (2007) found in another study that the rate at which it operates in each society differs and what accounts for such disparity is the operation of social comparison process and "the extent to which men and women use the stereotype of their group to define themselves" (see also Garcia, Branscombe, Desmarais, \& Gee, 2006). A factor that is believed to contribute to strong social comparison and gender difference is power distance culture (Hofstede, 1980, 2001; Bollinger \& Hofstede, 1987; Hofstede \& McCrae, 2004). This is a kind of cultural disposition whereby discrimination among persons holding different positions of power is viewed as a normal (and even desirable) aspect of the 
social order (Guimond et al., 2007). Such cultural disposition could be high or low. In the high power distance cultures, social hierarchy is taken seriously and thus it is considered wrong for people in different positions of power to share a vertical relationship with each other. The implication of this is that people who are privileged to assume power platform and those outside the scope are rarely compared socially. Social comparisons in this type of societies are rather restricted to intergroup level (Guimond et al., 2007).

Due to its communal nature, the Malaysian society has been constructed as operating based on collectivist culture whereby members see themselves as an integrated part of a micro society and construe themselves within the relational and interdependent sphere of their respective group (Markus \& Kitayama, 1991; Kashima et al., 1995). The collectivist culture has been described as one in which the individual members of the society tends to be more worried about how his or her actions is viewed by other members of the society and will be disposed to sacrificing his or her personal interest for the collective interest of his or her group (Smith, Dugan, Peterson and Leung, 1996; Mohd. Haniff Jedin and Norsafinas Md. Saad, 2006). Such person would not mind whether the interest is rightly or wrongly served. This attitude, while it may have served the community well also has been a primary force in the traditional gender role stereotyping.

\section{Data and Methodology}

This study is mainly exploratory. The Data came from the library and online documents. The library materials were mainly sourced from the Gombak Library of the International Islamic University Malaysia. Data analyses, therefore, involved qualitative content analysis of themes relevant to the discourse.

\section{Findings and Discussion}

\section{Stereotyping and typifying of women roles in the society}

It is found that the plight of the Malaysian women and the lack of their visible presence in nation building and national development is a result of the cultural stereotyping of the womenfolk as child bearers and home keepers. Examining the cause of gender differences from a psychological perspective, Guimond et al. (2007) noted that the general perception of gender differences in a society is a reflection of the process of stereotyping among the people whereby members of each gender group assume certain stereotypical attributes. What this implies 
is that both Malaysian men and women lived by the assumption that women are traditionally designed to be at the backstage and take care of domestic affairs. They are expected to be laid back and operate from the backstage.

It is found that Malaysia is one of the nations that score the highest mark for high power distance culture (Hofstede, 1980). This is because its societies operate based on certain norms that legitimise differences in power (Brockner et al., 2001). Consequently, the society is structured in a way that intra-group social comparisons between men and women are rarely done. Therefore, hardly would evidence be found comparing successes of women against those of their male counterparts especially at the level of national development. Another implication of this is that it has prevented the women from taking a strong self-construal analysis of themselves. In a research aimed at relating gender and culture to the use of language, a startling and related revelation was made. The female respondents that participated in the research construed themselves as being more talkative and emotional than the male participants who are construed as assertive and less able to show emotion (Leaper \& Smith 2004; Michaud, Bégin \& McDuff 2006; Balakrishnan \& Batat 2010; ). This result is supported by the view of a Malay female religious teacher who described women as narrow-minded, superficial, immature, emotional and inferior compared to men (Hanami, 2002). It is submitted that this perception is not always as natural as it seems but the society has imposed upon them how they should construe themselves (Wood, 1989), and they are contented with it. Thus they found themselves living within the stereotyped attributes of agreeableness, tenderness and taking care of relationships while men are supposed to be more assertive, ambitious and open to ideas (McCrae, et al., 2005; Faculty.Css.edu, n.d.). When attacked, males are expected to fight back but females should not (Faculty.Css.edu, n.d.).

The point here though is not to argue that women should act aggressively but there is nothing in the natural law that points to the fact that women cannot be assertive, ambitious and open to ideas, which are some of the attributes of good leaders. Therefore, by stereotyping the women to the attribute of outright submissiveness, their aspirations to be leaders and contribute to the national development have certainly been curtailed. The gist of this position is that what is considered as "masculine assertiveness" has been associated with high earnings, recognition for a good job, advancement in career and challenge to achieve personal accomplishments (Faculty.Css.edu, n.d.). 


\section{Paucity of women in decision-making positions}

The stereotyping of women roles and attitude via the high power distance culture reflects apparently in the Malaysian political structure which is dominated by the male while women only play complimentary roles. Although women carry about 50 percent of the Malaysian voters, the role they are being allowed to play in decision-making processes does not reflect this numerical strength (Wang Lay Kim, 2005). According to Kim, "women's penetration in higher posts ... is dismally small." For example, statistics have shown that in 2004, there were 531 male members of state parliaments but only 36 females; 16 parliamentary secretaries were male while only 6 were female; out of 38 deputy ministers, only 3 were female just like there were only 3 female cabinet ministers out of 33 (Off The Edge, 2005). Although admittedly, there has been some slight increase in the participation of women in the state and national politics, the number is still insignificant (Azman Azwan Azmawati, 2008). This gap has been observed by the United Nations (2005), which reported that despite their growing level of education (which evidently is surpassing the men), the opportunities provided to the women to participate in decision-making and hence nation building has been minimal because they are not given adequate chances of leading in vital political, economic and social fields. Although, it is recently found that the women comprise almost two-thirds of the Malaysian public service workforce, yet their rise in the service has generally been restricted to middle-management positions (United Nations, 2011, p.55). In a recent survey, it was found that although women constituted 56 percent of the Malaysian public service in 2008 with 61 percent of that population holding managerial positions (United Nations, 2011). They however comprise only 22.8 percent of the top management cadre (United Nations, 2011). This shows that even though there are more qualified women who are capable of heading government departments and Government-Linked Companies (GLCs), only a few are given a chance. Similarly, the representation of women in the political positions reflects this trend. In the 2011 United Nations report of the survey of the proportion of Malaysian women and men in the political life in the year 2008 , it was found that the women constituted only 8 percent of political office holders. Even the proportion of women at decision-making level in the corporate sector is also insignificant. Despite the large population of women in the sector, only 6.1 percent are found to be sitting on the Board of Directors while only 26.2 percent rise to the top management level (Malaysia Ministry of Women, Family and Community Development, 2008). 
One of the dire consequences of meagre participation of women in decision-making is likely lopsidedness in the fashioning developmental policies that will impact positively on their lives. Furthermore, the failure to integrate the women substantially into the mainstream of policy and decisionmaking processes will only further engender the high power distance cultural stance of the Malaysian society thereby isolating and discriminating against them (Hong, 1983).

One of the identified purposes of the vigorous pursuit of the MDGs is to ensure that Malaysia shirks isolationism and imbibe global partnership by working in tandem with developed nations while serving as the beacon of development for other developing nations (United Nations, 2005). But a critical look at the programmes outlined for women empowerment shows that the women appear not to be considered for any role in this regard. This could inform the paucity of women in high-profile positions where they could make developmental changes at a global level. This role could also be achieved by women as it has been done in other jurisdictions. Examples can be found in Margaret Thatcher of Britain, Condoleezza Rice and Hilary Clinton of the United States or Ngozi Okonjo-Iweala of Nigeria to mention but a few.

\section{Lack of strong political commitment to encourage wider participation of women in politics and leadership schemes}

Even though Malaysia has taken efforts to improve the status of the women, the small number of women who are given the opportunity to contribute to national development belies those efforts. For instance, the national mechanisms put in place by the country are ineffective in influencing political decisions that are capable of improving the position of women in national development (United Nations, 2010). Even, national mechanisms situated at the Cabinet or Prime Minister's offices have been found to be bypassed for supposedly more pressing concerns where there are competing demands (United Nations, 2010). There have several complaints by national women institutions that they are marginalised compared to other institutions (United Nations, 2010). Government supports have equally been low as such national women machinery suffers from low budget allocations, inadequate staffing and insufficient authority to liaise with related government departments at the lower level of implementation of relevant government policies (United Nations, 2010; ESCAP 2009). Many of these women empowerment machinery were established as administrative offices with no portfolio to make them operate actively in advocating for inclusion of women in high profile decisionmaking positions (United Nations, 2010). All these constraints point to the fact 
that the government though has objective geared towards elevating the status of women, the scope of the objective appears not to cover elevating their status politically. This explains why the political systems and structures of governance are still not fully imbued with concrete arrangements of how the women will be fully integrated into effective national policy making and implementation of those policies.

\section{Conclusion and Recommendations}

Women constitute a significant percentage of the Malaysian population. It has been found that more Malaysian women attain higher education than their male counterparts. However, these feats do not reflect in the allowance given to women to contribute more actively to national political efforts towards nation building and national development. This setback has been attributed to certain traditional practices that encourage stereotyping of gender roles between the men and the women. By this, the women are believed to be naturally created to contribute more to domestic and communal development while the men are expected to control the political front. While some writers have blamed this attitude on religion and culture, others have refuted this blame by showing that both the religions, especially Islam and cultures operating among the Malaysians encourage active participation of women in national politics so long it does not affect their other roles in the society.

The Malaysian government has taken some steps to bring women into active participation in politics but not so much to allow them participate more in the national decision-making process or holding national positions that will enable them to contribute to the efforts of the country to be among the world's developed nation. Some of the machinery put in place by the government have declined in the initial momentum while the goals for which they were established are yet to be met. This reflects in the disjunction between the educational achievements of the women and their physical presence and roles in national development. There is, therefore, the need to introduce fresh approaches and perspectives to the government's efforts to ensure that it keeps up its commitment at the millennium summit. It is believed that there would be an improvement in the Malaysian development if the Malaysian government harnesses the women's traditional roles as homemakers, domestic partners and friends.

It will be ordinarily expected that the growing level of women's education should translate equally to more participation in decision-making processes, but this apparently is not the case. It is, therefore, essential to 
provide more chances for the women to vie for and assume more primal leadership positions in political, social and economic spheres of the country. This could be achieved through many means among which include:

i. Introducing educational contents that will erase the entrenched gender stereotype awareness among the young generations;

ii. Media support in reconstructing the image of the women by changing the patriarchal perceptive that pervades the society through production of programmes that reflect non-stereotyped, balanced and diverse images of the women;

iii. Gender analysis, gender impact assessment should be entrenched in development planning by the government. Also, gender contributions assessment should also be institutionalised in governments' national plan with a view to comparing contributions made by members of each gender group towards national development in a given year.

iv. Rigorous efforts by the government to enlighten the people even from religious and traditional historical perspectives to move away from the traditional gender norms and break the patriarchal barrier;

v. The women national machineries must be strengthened more in order to help the government fulfil its commitment in the Beijing Platform for Action and consolidating its achievements in the MDGs;

vi. Advocacy efforts should be made towards the reorientation of conservative religious and power groups by making them realise that neither the religions nor the cultures operating in Malaysia prohibit the women from holding prime political offices;

vii. The government must improve its political commitment towards incorporating women in real phases of decision making.

viii. Women bodies should also work within the confines of religious principles to advocate for the eradication of gender disparity in legislative and executive political structures, especially at the national level. They should make more awareness campaign among the women to eradicate the gender stereotype perspective now entrenched in the society as against the open society created by both the religion and the traditional Malay adat. 


\section{References}

Abdul Jalil, Shahrizat. (2013). Wanita Umno: The pillar and backbone of Umno. Speech delivered at the Wanita Umno Annual General Meeting held at Putrajaya World Trade Centre on 4 December 2013.

Abdullah, S. (2011). Thematic Approaches in Malaysian Arts Since The 1990s. JATI, 16 (December 2011), 97-112.

Ali, Mumtaz and David, Maya Khemlani. (2013). Communication Enhances

Community Participation (CECP): A Testimony of an NGO in Malaysia. JATI, 18 (December 2013), 207-222.

ADB. (1975). Labour Force Survey Report, Peninsular Malaysia, 1975, Kuala Lumpur.

- - (1980). Labour Force Survey Report, Malaysia, 1980, Kuala Lumpur.

- - (1990). Labour Force Survey Report, Malaysia, 1990, Kuala Lumpur.

- - (1998). Labour Force Survey Report, Malaysia, 1997, Kuala Lumpur.

- - (2000). Population and Housing Census of Malaysia: Economic

Characteristics of the Population, Kuala Lumpur.

- - (2000). Labour Force Survey Report, Malaysia, 2000, Kuala Lumpur.

- - (2002). Labour Force Survey Report, Malaysia, 2002, Kuala Lumpur.

- - (2003). Labour Force Survey Report, Malaysia, 2003, Kuala Lumpur.

- - (2007). Key Indicators 2007: Inequality in Asia. Manila: ADB.

Ahmed, D. S. (ed.). (2002). Gendering the Spirit, Women, Religion and the Post-Colonial Response. London and New York: Zed Books

Azman Azwan Azmawati \& Juliana Abdul Wahab. (2005). Power and Patriarchy: Women's programmes on Malaysian television, Paper delivered at the 14th AMIC Annual Conference Media and Society in Asia: Transformation and Transition Beijing, People's Republic of China.

Azman Azwan Azmawati. (2008). Cultivating gender-sensitive culture in the Malaysian media industry: a critique and an alternative. Retrieved from

http://eprints.usm.my/4896/1/Cultivating_Gender_Sensitive_Culture_I n_The_Malaysian_Media_Industry.pdf on 5 December 2013.

Badarana. (2014). Tun Dr. Mahathir and the Malays. Din Merican: The Malaysian DJ Blogger. 27 September 2014. Retrieved from https://dinmerican.wordpress.com/2014/09/17/tun-dr-mahathir-andthe-malays/ on 25 December 2013.

Balakrishnan, V. \& Batat, W. (2010). Text messaging culture among youths: Comparing Malaysian and French youths. E-Book: Global sustainable 
Driving from the Backseat: An Exploratory Study of the Dearth of Malaysian Women in Political Decision-Making Process

development: A challenge for consumer citizens. Retrieved from www.educationforsustainabledevelopment.org on 30 December 2011.

Bollinger, D., \& Hofstede, G. (1987). Les diffe'rences culturelles dans le management: Comment chaque pays ge rent-ils ses hommes? [Cultural differences in management: How each country lead its people]. Paris: Les e'ditions d'organisation.

Brockner, J., Ackerman, G., Greenberg, J., Gelfand, M. J., Francesco, A.-M., Chen, Z. X., et al. (2001). Culture and procedural justice: The influence of power distance on reactions to voice. Journal of Experimental Social Psychology, 37, 300-315.

Country Meters. (2014). "Malaysian Population Clock". retrieved from http://countrymeters.info/en/Malaysia on 25 December 2014 at 4:25 pm.

ESCAP. (2009). "Financing and accountability for gender equality and women's empowerment" background paper for the High-level Intergovernmental Meeting to Review Regional Implementation of the Beijing Platform for Action and Its Regional and Global Outcomes, Bangkok, 16-18 November 2009.

Faculty.Css.edu. (n.d.). Cultural Dimensions. Retrieved from http://faculty.css.edu/dswenson/web/CULTURE/CULTDIM.HTM on 16 January 2014.

Garcia, D. M., Branscombe, N. R., Desmarais, S., \& Gee, S. S. (2006). Attitudes toward redistributive social policies: The effects of social comparisons and policy experience. In S. Guimond (Ed.), Social comparison and social psychology: Understanding cognition, intergroup relations and culture (pp. 151-173). Cambridge, England: Cambridge University Press.

Gross, R. (1993). Buddhism after Patriarchy. Albany, NY: University of New York Press.

Guimond, S., Branscombe, N. R. Brunot, S., Buunk, A. P., Chatard, A., De'sert, M., Garcia, D. M., Shamsul Haque, Martinot, D. \& Yzerbyt, V. (2007). Culture, Gender, and the Self: Variations and Impact of Social Comparisons Processes. Journal of Personality and Social Psychology, 92 (6), 1118-1134.

Guimond, S., Chatard, A., Martinot, D., Crisp, R., \& Redersdorff, S. (2006). Social comparison, self-stereotyping, and gender differences in selfconstruals. Journal of Personality and Social Psychology, 90, 221-242.

Haji Faisal bin Haji Othman. (1984). Women and Nation Building: Systematic and Historical Analysis of the problem of women in Islam with special reference to 
the situation in Malaysia. Michigan: U.M.I. Dissertation Information Services.

Hofstede, G. (1980). Culture's consequences: International differences in workrelated values. Beverly Hills, CA: Sage.

Hofstede, G. (2001). Culture's consequences: Comparing values, behaviors, institutions, and organizations across nations (2nd ed.). Thousand Oaks, CA: Sage.

Hofstede, G., \& McCrae, R. R. (2004). Personality and culture revisited: Linking traits and dimensions of culture. Cross-Cultural Research, 38, 52-88.

Hong, E. (1983). Rural Women in Development. In Hong, Evelyn (Ed.). Malaysian Women: Problems and Issues. Penang: Consumers' Association Penang.

Inoguchi, T. and E. Newman (1997). "Introduction: Asian Values and Democracy in Asia". Proceedings of a conference as part of the First Shizuoka Asia-Pacific Forum: The Future of the Asia-Pacific Region, Hamamatsu, Shizuoka, 28 March 1997.

Ka Chuan, Ong. (2006). Ka Chuan: Boys not studying hard. The Star Online. 10 July 2006. Retrieved from http://www.thestar.com.my/story/?file=\%2f2006\%2f7\%2f $10 \% 2 \mathrm{fnation} \%$ 2f14789867\&sec=nation on 25 December 2014.

Kalthom Abdullah, Noraini M. Noor and Saodah Wok. (2008). The Perceptions of Women's Roles and Progress: A Study of Malay Women. Soc Indic Res, DOI 10.1007/s11205-008-9242-7.

Kashima, Y., Yamagushi, S., Kim, U., Choi, S.-C., Gelfand, M. J., \& Yuki, M. (1995). Culture, gender, and self: A perspective from individualismcollectivism research. Journal of Personality and Social Psychology, 69, 925 937.

Kaur, K. and Shaari, H. (2012). Women Political Candidates-The Malaysian Media and Their Concerns. Journalism and Mass Communication, 2 (1), 385-398.

Khalili, A. (n.d.). Gender Differences in Emotional Intelligence AmongEmployees of Small and Medium Enterprise: An Empirical Study. Retrieved from http://www.jimsjournal.org/19\%20Ashkan\%20Khalili.pdf on 25 December 2014.

Kim, W. L. (1994). Gender and the New Communication Technology in Malaysia. Sojourn: Journal of Social Issues in Southeast Asia. 9 (2), 213-225. 
Driving from the Backseat: An Exploratory Study of the Dearth of Malaysian Women in Political

Leaper, C \& Smith.T.E. (2004). A meta-analytic review of gender variations in children's language use: talkativeness, affiliative speech, and assertive speech. Developmental Psychology. 40 (6), 993-1027.

Makiko Hanami. (2002). Gender in a rural Malay Community: Between Adat and Islam. Ann Arbor, MI: ProQuest Information and Learning Services.

Malaysia, Department of Statistics. (1972). Social Statistics Bulletin, Malaysia, 1972, Kuala Lumpur.

Malaysia Ministry of Women, Family and Community Development. (2008). Statistics on Women, Family, and Social Welfare, 2008. Kuala Lumpur.

Mananzan, M. J. (2004). Women, Religion, and Spirituality in Asia. Manila: Anvil Publishing and Institute of Women's Studies.

Markus, H., \& Kitayama, S. (1991). Culture and the self: Implications for cognition, emotion, and motivation. Psychological Review, 98, 224-252.

Mazruki, N. A., Mustaffa, C. S., Muda, Z. M. S., Abdullah, S. and Din, W. B. C. (2012). Emotional intelligence and demographic differences among students in public universities. Research Journal of Organizational Psychology \& Educational Studies. 1 (2), 93-99.

McCrae, R. R., Terracciano, A., \& 78 members from the Personality Profiles of Culture Project. (2005). Universal features of personality traits from the observer's perspective: Data from 50 cultures. Journal of Personality and Social Psychology, 88, 547-561.

Michaud, J. Bégin. H \& McDuff, P. (2006). Construction et évaluation d'un questionnaire sur l'estime de soi sociale destiné aux jeunes adultes [Construction and initial validation of a new scale intended to measure social self-esteem in young adults]. Revue Europeenne de Psychologie Appliquee/European Review of Applied Psychology. 56 (2), 109-122.

Mohd. Hamdan Adnan. (1987). Women and the media in Malaysia. Media Asia. 14.

Mohd. Haniff Jedin \& Norsafinas Md. Saad. (2006). A preliminary study on gender and learning style in Malaysian higher learning institutions: Evidence from a cultural perspective. HERDSA, 138-145.

Mohd. Haniff Jedin and Norsafinas Md. Saad. (2006). A preliminary study on gender and learning style in Malaysian higher learning institutions: Evidence from a cultural perspective. Retrieved from www.herdsa.org.au/wp-content/uploads/conference/2006/Haniff.pdf on 5 December 2013.

Ngah, R. (2009). Emotional Intelligence of Malaysian Academia towards Work Performance. International Education Studies. 2 (2), 103-112. 
OECD (2009). "Managing for agency gender equality results in partner countries". $\quad$ Retrieved from www.oecd.org/dataoecd/49/19/42936177.pdf on 20 February 2010.

Off The Edge (2005) Vital Statistics Special. The Edge Communications Sdn Bhd: Selangor.

Pua, Tony. (2006). Girls Smarter Than Boys? (II). Education in Malaysia. 19 July 2006. Retrieved from educationmalaysia.blogspot.com/2006/07/girlssmarter-than-boys-ii.html on 25 December 2014.

Pua, Tony. (2005). Girls Smarter Than Boys? Education in Malaysia. 20 July 2005.

Retrieved from http://educationmalaysia.blogspot.com/2005/07/girlssmarter-than-boys.html on 25 December 2014.

Rahimy, Rahim. (2014). Dr M: I failed to change lazy Malays. The Star Online. 11 September 2014. Retrieved from http://www.thestar.com.my/News/Nation/2014/09/11/mahathirmohamad-says-he-failed-to-change-lazy-malay-mindset/ on 25 December 2014.

Rosenlee, L.-H. L. (2006). Confucianism and Women: A Philosophical Interpretation. Albany, NY: State University of New York.

Smilling. (2011). Gender Equality in Malaysia. Retrieved from http://www.studymode.com/essays/Gender-Equality-In-Malaysia779745.html on 5 December 2013.

Smith, P. B., Peterson, M. F. and Leung, K. (1998). Individualism: Collectivism and the handling of disagreement. A 23 country study. International Journal of Intercultural Relations, 22 (3), 351-367.

Tan, Joceline. (2014). Don't 'play-play' with the women. The Online Star. 27 November 2014. Retrieved from http://www.thestar.com.my/Opinion/Columnists/Analysis/Profile/Arti cles/2014/11/27/Dont-playplay-with-the-women/ on 25 December 2014.

UMNO Wanita: Shahrizat wants more women decision-makers in govt and GLCs. (2013). ABN News. 4 December 2013. http://news.abnxcess.com/2013/12/umno-wanita-shahrizat-wantsmore-women-decision-makers-in-govt-and-glcs/ on 25 December 2014.

United Nations (2011). Malaysia: The Millennium Development Goals at 2010. Kuala Lumpur: United Nations Country Team, Malaysia.

United Nations. (2010). Strengthening National Mechanisms for Gender Equality and the Empowerment of Women: Regional Study - Asia and the Pacific. Bangkok: United Nations. 
Driving from the Backseat: An Exploratory Study of the Dearth of Malaysian Women in Political

United Nations. (2005). Malaysia: Achieving the Millennium Development Goals: Successes and Challenges. Kuala Lumpur: United Nations Country Team, Malaysia.

Wang Lay Kim \& Mustafa Kamal Anuar. (1996). 'Aspects of ethnicity and gender in Malaysian television'. In D. French and M. Richards (Ed), Television: Eastern Perspective, 262-281. London: Sage.

Wang Lay Kim. (2005). Ways of Seeing Women: Sketches of Women in Magazines in the Global Age. Paper presented at the International Conference on Media and Communication: Communication, Globalization and Cultural Identities. Putrajaya: Universiti Kebangsaan Malaysia.

Wazir Jahan Karim. (1992). Women and Culture: Between Malay Adat and Islam. Oxford: Westview Press, Inc.

What is Shahrizat up to? Now Wanita Umno wants VP post. (2014). In Malaysia Chronicle. 30 August 2014. Retrieved from http://www.malaysia-

chronicle.com/index.php?option=com_k2\&view=item\&id=349551:what -is-shahrizat-up-to?-now-wanita-umno-wants-vp-post\&Itemid=2 on 25 December 2014.

Williams, J. E., \& Best, D. L. (1986). Sex stereotypes and intergroup relations. In S. Worchel \& W. G. Austin (Eds.), Psychology of intergroup relations (pp. 244-259). Chicago: Nelson-Hall.

Women's Aid Organisation. (2001). Status Report: Women\'s Equality in Malaysia. 1 March 2001. Retrieved from http://www.wao.org.my/news_details.php?nid=13\&ntitle=Status+Report :+Womens+Equality+in+Malaysia on 5 December 2014.

Wood, J. V. (1989). Theory and research concerning social comparisons of personal attributes. Psychological Bulletin, 106, 231-248.

Yuen Chee Keong, Saran Kaur Gill, Maisarah Noorezam \& Asma'a Abdulrazaq. (2012). Gender Differences and Culture in English Short Message Service Language among Malay University Students. The Southeast Asian Journal of English Language Studies. 18 (2), 67-74. 